\title{
PENGETAHUAN SIKAP DAN TINDAKAN PETUGAS PUSKESMAS TERHADAP SISTEM PENGELOLAAN SAMPAH MEDIS DI PUSKESMAS LUMPUE KOTA PAREPARE
}

\section{Knowledge of Attitude and Action of Health Center on Medical Waste Management System in Puskesmas Lumpue Parepare City}

\author{
Muh Adrianto, H. Ramlan, H. Abdul Madjid \\ Program Studi Kesehatan Masyarakat Fakultas Ilmu Kesehatan Universitas Muhammadiyah Parepare \\ (muhammadadrianto014@gmail.com)
}

\begin{abstract}
ABSTRAK
Dewasa ini limbah merupakan masalah yang cukup serius, terutama dikota-kota besar, sehingga banyak upaya yang dilakukan oleh pemerintah daerah, swasta maupun secara swadaya oleh masyarakat untuk menanggulanginya, dengan cara mengurangi, mendaur ulang maupun memusnahkannya. Sampah medis adalah bahan buangan yang dihasilkan dari kegiatan pelayanan medis baik diagnose maupun terapi kepada pasien. Tujuan penelitian ini untuk mengetahui gamabaran pengetahuan sikap dan tindakan petugas puskesmas terhadap sistem pengelolaan sampah medis di Puskesmas Lumpue Kota Parepare. Metode yang digunakan dalam penelitian ini adalah bersifat menggambarkan atau deskriptif. Analisa data menggunakan analisa univariat. Berdasarkan hasil penelitian diperoleh gambaran pengetahuan petugas Puskesmas Lumpue Kota Parepare dengan kategori tinggi yaitu 51,0\%, tingkat sedang 38,8\% dan rendah $10,2 \%$. Sedangkan gambaran sikap dan tindakan petugas Puskesmas Lumpue Kota Parepare dengan kategori baik yaitu 91,8\% dan kategori kurang baik $8,2 \%$. Berdasarkan penelitian ini tingkat pengalaman kerja seseorang sudah dapat memberikan sumbangan pengetahuan tentang pengelolan sampah medis. Sedangkan sikap dan tindakan petugas puskesmas tentang sistem pengelolaan sampah medis sudah baik. Hal ini disebabkan karena sudah tersedianya fasilitas-fasilitas yang menunjang terlaksananya sistem pengelolaan sampah medis di Puskesmas Lumpue Kota Parepare.
\end{abstract}

Kata kunci : Perilaku petugas, sikap petugas, tindakan petugas, sampah medis

\section{ABSTRACT}

. Nowadays, waste is a serious problem, especially in big cities, so that many efforts are made by local governments, private and self-help by the community to overcome it, by reducing, recycling and destroying it. Medical waste is waste material produced from medical service activities both in diagnosis and therapy to patients. The purpose of this study was to find out the knowledge of the attitudes and actions of puskesmas officers on the medical waste management system at the Lumpue Health Center in Parepare City. The method used in this study is descriptive or descriptive. Data analysis using univariate analysis. Based on the results of the study, it was obtained a description of the knowledge of officers of the Parepare City Lumpue Health Center with a high category of $51.0 \%$, a moderate level of $38.8 \%$ and a low of $10.2 \%$. While the description of the attitudes and actions of Parepare City Lumpue Public Health Center officers with a good category of $91.8 \%$ and $8.2 \%$ poor category.Based on this research, the level of work experience someone has been able to contribute to knowledge about medical waste management. Based on this research, the level of work experience someone has been able to contribute to knowledge about medical waste 
management. Based on this research, the level of work experience someone has been able to contribute to knowledge about medical waste management

Keywords: Behavior of officers, attitudes of officers, actions of officers, medical waste 


\section{PENDAHULUAN}

Tujuan Pembangunan Kesehatan, Indonesia Sehat 2020 adalah meningkatkan kesadaran, kemauan dan kemampuan hidup sehat bagi setiap orang agar terwujud Kesehatan yang optimal melalui terciptanya masyarakat, bangsa dan negara yang ditandai oleh penduduknya yang hidup dengan perilaku dan dalam lingkungan yang sehat, memiliki kemampuan untuk menjaga pelayanan Kesehatan yang bermutu secara adil dan merata. Serta memiliki derajat Kesehatan yang optimal di seluruh wilayah Republik Indonesia.

Faktor lain yang menyebabkan permasalahan sampah di Indonesia semakin rumit adalah meningkatnya taraf hidup masyarakat, yang tidak disertai dengan keselerasan pengetahuan tentang pengelolaan sampah dan juga partisipasi masayarakat yang kurang untuk memelihara kebersihan dan membuang sampah pada tempatnya. ${ }^{1}$

\section{Seringkali Puskesmas kehilangan} citranya dan berubah fungsinya menjadi tempat yang memberi kesan tidak teratur, kotor, tidak nyaman, berbahaya dan sebagainya.Salah satu penyebab yang cukup berperan dalam menciptakan kondisi Puskesmas yang sedemikian adalah kurangnya perhatian terhadap sanitasi Puskesmas tersebut. Menurut Hendrik L. Blum (2009), derajat Kesehatan dipengaruhi oleh berbagai faktor yaitu faktor lingkungan, perilaku, pelayanan Kesehatan dan keturunan. ${ }^{2}$
Limbah yang di hasilkan oleh Puskesmas dapat berbentuk padat, cair, dan gas. Limbah padat adalah semua limbah yang berbentuk padat sebagai akibat kegiatan yang terdiri dari limbah medis padat (sampah medis) dan non medis. Limbah medis padat adalah limbah padat yang terdiri dari limbah infeksius, limbah patologi, limbah benda tajam, limbah farmasi, limbah sitotoksis, limbah kimiawi, limbah radioaktif, limbah kontainer bertekanan, dan limbah dengan kandungan logam berat yang tinggi. ${ }^{3}$

Dewasa ini limbah merupakan masalah yang cukup serius, terutama dikotakota besar, sehingga banyak upaya yang dilakukan oleh pemerintah daerah, swasta maupun secara swadaya oleh masyarakat untuk menanggulanginya, dengan cara mengurangi, mendaur ulang maupun memusnahkannya. Namun semua itu hanya bisa dlakukan bagi limbah yang dihasilkan oleh rumah tangga saja.Lain halnya dengan limbah yang di hasilkan dari upaya medis seperti Puskesmas, Poliklinik, dan Rumah Sakit. Karena jenis limbah yang dihasilkan termasuk dalam kategori biohazard yaitu jenis limbah yang sangat membahayakan lingkungan, dimana disana banyak terdapat buangan virus, bakteri maupun zat-zat yang membahayakan lainnya, sehingga harus dimusnahkan dengan jalan dibakar dalam suhu diatas 800 derajat celcius. $^{4}$

Puskesmas dan instansi kesehatan lainnya memiliki "kewajiban untuk 
memelihara" lingkungan dan kesehatan

masyarakat, serta memilki tanggung jawab khusus yang berkaitan dengan limbah yang dihasilakan instansi tersebut. Kewajiban yang dipikul instansi tersebut di antaranya adalah kewajiban untuk memastikan bahwa penanganan, pengelolaan serta pembuangan limbah yang mereka lakukan tidak akan menimbulkan dampak yang merugikan kesehatan dan lingkungan.

Petugas Puskesmas Lumpue Kota Parepare yang terlibat langsung dan berperan besar dalam pengelolaan sampah medis dari tahap pengumpulan sampai tahap pembuangan akhir. Sudah memenuhi syarat dan berdasarkan pengalaman kerja seseorang sudah dapat memberikan sumbangan pengetahuan.

Dari survei awal yang dilakukan di Puskesmas Lumpue Kota Parepare, data kunjungan selama 3 tahun terakhir terus mengalami peningkatan, hal ini tergambar dari rata-rata kunjungan yang meningkat dari 47.308 tahun 2015 menjadi 52.346 tahun 2017. Hal ini di sebabkan karena luar kota Parepare. Sehingga sampah yang dihasilkan Puskesmas Lumpue Kota Parepare cukup tinggi. Maka dari itu, pengelolaan sampah khususnya sampah medis perlu mendapatkan perhatian yang serius. Oleh karena itu petugas Puskesmas Lumpue memiliki tanggung jawab yang sangat besar dalam pengelolaan sampah medis, untuk memelihara lingkungan dan kesehatan masyarakat, namun belum diketahui sejauh mana tingkat pengetahuan yang dimiliki petugas tersebut. ${ }^{5}$

Melihat permasalahan tersebut diatas maka timbul niat penulis untuk mengetahui bagaimana tingkat pengetahuan sikap dan tindakan atau gambaran mengenai perilaku petugas Puskesmas terhadap sistem pengelolaan sampah medis di Puskesmas Lumpue Kota Parepare.

\section{BAHAN DAN METODE}

Metode penelitian yang digunakan dalam penelitian ini bersifat menggambarkan atau deskriptif. Penelitian akan dilaksanakan di Puskesmas Lumpue Kota Parepare dan dilakukan pada bulan juni sampai agustus tahun 2018. Populasi dalam penelitian ini adalah Petugas Puskesmas Lumpue Kota Parepare sebanyak 97 orang. Pengambilan sampel dalam penelitian ini dilakukan dengan cara nonprobability sampling dengan jenis aksidental sampling. Jumlah sampel dalam penelitian ini yaitu sebanyak 49 sampel.

\section{HASIL}

Penelitian ini dilaksanakan di Puskesmas Lumpue Kota Parepare, Pengumpulan data dilaksanakan mulai bulan Juni sampai Agustus 2018 dengan berpedoman pada kuesioner yang berjumlah 49 responden. Jumlah petugas berdasarkan jenis kelamin pada tabel 1 yang terbanyak terdapat pada kelompok perempuan sebayak 42 orang yaitu $85,7 \%$ dan kelompok laki-laki 
sebayak 7 orang yaitu $14,3 \%$. Jumlah petugas berdasarkan umur pada Tabel 2 yang tertinggi pada umumnya umur 20-30 tahun yaitu $63,3 \%$. Jumlah petugas berdasarkan lama kerja pada Tabel 3 yang terbanyak antara 1-10 tahun yaitu 81,6\% lama kerja antara 11-20 tahun yaitu 14,3\% dan lama kerja antara 21-30 tahun yaitu $4,1 \%$. Jumlah petugas berdasarkan tingkat pendidikan terakhir pada Tabel 4 terbanyak terdapat pada tingkat pendidikan Strata satu (S1) yaitu $57,1 \%$, tingkat pendidika Diploma tiga (DIII) yaitu 42,9\%. Jumlah petugas berdasarkan pengetahuan pada Tabel 5 terbanyak pada umumnya tingkat tinggi yaitu $51,0 \%$, tingkat sedang $38,8 \%$ dan tingkat rendah $10,2 \%$. Jumlah petugas berdasarkan sikap pada Tabel 6 terbanyak terdapat pada kategori baik 91,8\% dan kategori kurang baik $8,2 \%$. Jumlah petugas berdasarkan tindakan pada Tabel 7 terbanyak terdapat pada kategori baik $91,8 \%$ dan kategori kurang baik 8,2\%.

\section{PEMBAHASAN}

Hasil penelitian menunjukkan bahwa dari 49 responden, pengetahuan petugas puskesmas terhadap sistem pengelolaan sampah medis di Puskesmas Lumpue Kota Parepare. Hasil penelitian terbanyak terdapat pada umumnya tinggi $51,0 \%$. Hal ini disebabkan oleh salah satu faktor yaitu sebagian besar responden mempunyai pengalaman kerja 1-10 tahun $81,6 \%$ sehingga berdasarkan pengalaman kerja mereka dapat mengetahui tentang sistem pengelolaan sampah medis di Puskesmas.

Berdasarkan hasil penelitian tentang pengetahuan petugas Puskesmas terhadap sistem pengelolaan sampah medis di Puskesmas Lumpue Kota Parepare dapat diketahui bahwa sebagian besar petugas mempunyai pengetahuan yang tinggi terhadap pengelolaan sampah medis.

Hal ini dapat diketahui bahwa meskipun tingkat pengetahuan petugas puskesmas terhadap pengelolaan sampah medis tinggi, Belum tentu akan menghasilkan sistem pengolahan yang baik pula. Hal ini dapat dipahami karena menurut Notoadmodjo 2010. Pengetahuan adalah merupakan hasil tahu dan ini terjadi setelah orang melakukan pengideraan terhadap suatau objek tertentu dan bukan merupakan satu bentuk kegiatan.

Hasil penelitian menunjukkan bahwa dari 49 responden, sikap dan tindakan petugas puskesmas terhadap sistem pengelolaan sampah medis di Puskesmas Lumpue Kota Parepare. Jumlah petugas berdasarkan sikap dan tindakan terbanyak terdapat pada umumnya baik $91,8 \%$.

Berdasarkan hasil penelitian ini disebabkan oleh salah satu faktor yaitu ketersediaan fasilitas-fasilitas yang mendukung pelaksanaan pengelolaan sampah medis dan non medis tersebut, tempat-tempat pembuangan sampah medis dan non medis diletakkan di depan atau di dalam ruangan tindakan petugas kesehatan, hal ini juga 
merupakan salah satu alasan bagi petugas untuk lebih mudah dalam membuang limbah medis dan non medis. tempat sampah yang sudah disediakan dengan sesuai spesifikasinya akan lebih mudah untuk petugas dalam pengelolaannya.

Seperti dikemukakan oleh Hedrik L. Blum (2009) bahwa beberapa faktor yang mempengaruhi derajat kesehatan adalah faktor lingkungan, perilaku, pelayanan kesehatan dan keturunan. Keempat faktor tersebut bukan saja berpengaruh terhadap derajat kesehatan akan tetapi juga saling berinteraksi satu sama lain. ${ }^{2}$

Lingkungan yang mendukung gaya hidup bersih juga berperan dalam meningkatkan derajat kesehatan masyarakat. Perilaku yang sehat akan menunjang meningkatnya derajat kesehata, hal ini dapat dilihat dari banyaknya penyakit berbasis perilaku dan gaya hidup.

Ketersedian fasilitas dengan mutu pelayanan yang baik akan mempercepat perwujudan derajat kesehatan masyarakat. Dengan menyediakan fasilitas pelayanan kesehatan yang bermutu secara merata dan terjangkau akan meningkatkan akses masyarakat ke fasilitas pelayanan kesehatan. Ketersediaan fasilitas tentunya harus ditopang dengan tersedianya tenaga kesehatan yang merata dan cukup jumlahnya serta memiliki kompetensi di bidangnya.

Kondisi makhluk hidup ditentukan oleh keadaan gen orang tuanya. Adanya kelainan atau kecacatan pada gen orang tua akan mengakibatkan timbulnya kelainan/penyakit yang bersifat bawaan pada keturunan. Sehingga dapat diambil satu kesimpulan bahwa status kesehatan masyarakat akan tercapai secara optimal apabila keempat faktor tersebut juga mempunyai kondisi yang optimal.

\section{KESIMPULAN DAN SARAN}

Berdasarkan hasil diatas, maka dapat disimpulkan bahwa tingkat pengetahuan petugas Puskesmas di Puskesmas Lumpue Kota Parepare pada umumnya tinggi 51,0\%. Tingkat sikap petugas puskesmas di Puskesmas Lumpue Kota Parepare pada umumnya baik $91,8 \%$. Dan tingkat tindakan petugas puskesmas di Puskesmas Lumpue Kota Parepare pada umumnya baik 91,8\%. Dengan kesimpulan diatas maka di sarankan Bagi petugas Puskesmas agar lebih meningkatkan pengetahuan sikap dan tindakan terhadap sistem pengelolaan sampah medis. Untuk mencapai kesehatan yang bermutu secara adil dan merata. Serta memiliki derajat Kesehatan yang optimal di seluruh wilayah Republik Indonesia. Bagi penelitian yang akan datang dapat dijadikan sebagai acuan dan diharapkan mengambil populasi yang lebihpesifik dan lebih besar dengan gambaran lebih lanjut. 


\section{DAFTAR PUSTAKA}

1. Slamet. Hubungan Pengetahuan dan Sikap masyarakat dengan Pengelolaan Sampah di Desa Loli Tasiburi Kecamatan Banawa Kabupaten Donggala [Jurnal Online].2010. [Di Akses pada tanggal 14 November 2018]. Available at Journal.uin-alauddin.ac.id.

2. Hendrik. Faktor-faktor yang Mempengaruhi Kesehatan [Serial Online]. 2009. [Di akses pada tanggal 14 November 2018] Available at idahceris.wordpress.com.
3. Kepmenkes RI. Limbah yang di hasilkan oleh Puskesmas [Serial Online]. 2004. [Di akses pada tanggal 14 November 2018] Available at www.pdpersi.co.id.

4. Maxpellechnology. Jenis Limbah [Serial Online]. 2008. [Di akses pada tanggal 14 November 2018] Available at Idahceris.wordpress.com.

5. Puskesmas,Lumpue. Data Kunjungan Survei Parepare . Parepare: Puskesmas Lumpue; 2015. 


\section{LAMPIRAN}

Tabel 1. Distribusi Responden Berdasarkan Jenis Kelamin di Puskesmas Lumpue Kota Parepare Tahun 2018

\begin{tabular}{ccc}
\hline Jenis kelamin & Frekuensi & Persentase (\%) \\
& & 14,3 \\
Laki-laki & 7 & 85,7 \\
\hline Permpuan & 42 & 100 \\
\hline Total & 49 & Pal
\end{tabular}

Tabel 2. Distribusi Responden Berdasarkan Umur di Puskesmas Lumpue Kota Parepare Tahun 2018

\begin{tabular}{lccc}
\hline & Umur & Frekuensi & Persentase $(\%)$ \\
\hline 20-30 tahun & & 31 & 63,3 \\
$31-40$ tahun & I2 & 24,5 \\
$41-50$ tahun & 4 & 8,2 \\
$>51$ tahun & & 2 & 4,0 \\
\hline \multicolumn{2}{c}{ Total } & 49 & 100 \\
\hline
\end{tabular}

Table 3. Distribusi Responden Berdasarkan Lama Kerja di Puskesmas Lumpue Kota Parepare Tahun 2018

\begin{tabular}{|c|c|c|}
\hline Lama kerja & Frekuensi & Persentase $(\%)$ \\
\hline $1-10$ tahun & 40 & 81,6 \\
\hline 11-20 tahun & 7 & 14,3 \\
\hline 21-30 tahun & 2 & 4,1 \\
\hline Total & 49 & 100 \\
\hline
\end{tabular}

Table 4. Distribusi Responden Berdasarkan Pendidikan Terakhir di Puskesmas Lumpue Kota Parepare Tahun 2018

\begin{tabular}{ccc}
\hline Pendidikan terakhir & Frekuensi & Persentase $(\%)$ \\
\hline Pendidikan Diploma tiga (DIII) & 21 & 42,9 \\
Pendidikan Strata satu (SI) & 28 & 57,1 \\
\hline Total & 49 & 100 \\
\hline
\end{tabular}

Tablel 5. Distribusi Responden Berdasarkan Pengetahuan di Puskesmas Lumpue Kota Parepare Tahun 2018 


\begin{tabular}{|c|c|c|}
\hline Tinggi & 25 & 51,0 \\
\hline Sedang & 19 & 38,8 \\
\hline Rendah & 5 & 10,2 \\
\hline Total & 49 & 100 \\
\hline
\end{tabular}

Tabel 6. Distribusi Responden BerdasarkanSikap di Puskesmas Lumpue Kota Parepare Tahun 2018

\begin{tabular}{|c|c|c|}
\hline sikap & Frekuensi & Persentase $(\%)$ \\
\hline Baik & 45 & 91,8 \\
\hline Kurang baik & 4 & 8,2 \\
\hline Total & 49 & 100 \\
\hline
\end{tabular}

Tabel 7. Distribusi Responden Berdasarkan Tindakan di Puskesmas Lumpue Kota Parepare Tahun 2018

\begin{tabular}{|c|c|c|}
\hline Tindakan & Frekuensi & Persentase (\%) \\
\hline Baik & 45 & 91,8 \\
\hline Kurang baik & 4 & 8,2 \\
\hline Total & 49 & 100 \\
\hline
\end{tabular}

